\title{
KAJIAN PRODUKTIVITAS TANAMAN AREN BERDASARKAN SIFAT MORFOLOGI TANAMAN PADA SKUEN TINGGI TEMPAT DI KABUPATEN TAPANULI SELATAN
}

\author{
Darmadi Erwin Harahap \\ Program Studi Agroteknologi, Fakultas Pertanian \\ Universitas Graha Nusantara, Padangsidimpuan \\ Corresponding author :E- mail: erwindarmadi@yahoo.com
}

\begin{abstract}
ABSTRAK
Penelitian ini bertujuan Untuk mengetahui hubungan sifat morfologi tanaman terhadap produksinya berdasarkan skuen ketinggian tempat di Kabupaten Tapanuli Selatan. Lokasi yang menjadi kajian penelitian ini berdasarkan skuen tinggi tempat di Daerah Kabupaten Tapanuli Selatan. Sample tanaman diambil di Desa Situmba dan Desa Panabari Kecamatan Tano Tombangan Angkola dengan ketinggian 0 - $400 \mathrm{~m}$ dpl, Desa Pasar Sempurna, Desa Gunungtua, Desa Aek Nabara Kecamatan Marancar dengan ketinggian 400 - $800 \mathrm{~m}$ dpl dan Desa Sialaman Julu, Desa Sialaman Jae Kecamatan Sipirok dengan ketinggian $>800 \mathrm{~m}$ dpl. Pengamatan terhadap perkembangan morfologi tanaman aren di lapangan dilakukan terhadap parameter Tinggi Tanaman, Umur Tanamam, Diameter Batang, Umur Sadapan, Tingkatan Malai, dan Jumlah Klorofil a dan b. Hasil penelitian menunjukkan bahwa yang paling berpengaruh terhadap produksi produksi nira adalah Tinggi Tanaman dan Umur tanaman (37,2 \%), sedangkan untuk produksi gula yang paling berpengaruh adalah tinggi tanaman $(29,2 \%)$.
\end{abstract}

Kata Kunci : Aren, Sifat Morfologi, Skuen, Tapanuli, Selatan

\section{PENDAHULUAN}

Kabupaten Tapanuli Selatan adalah Kabupaten Induk yang sudah dimekarkan menjadi 4 Kabupaten dan 1 Kotamadya, dimana dari sekian luas hutannya banyak tumbuh tanaman aren liar. Desa Pasar Minggu Kabupaten Tapanuli Selatan dengan ketinggian $500 \mathrm{dpl}$, aren yang dikelola oleh petani dapat menghasilkan nira sebanyak 25 liter/hari dengan rincian panen pagi hari menghasilkan 15 liter dan sore hari 10 liter/batang.

Perhatian terhadap tanaman aren ini masih sangat minim sehingga tanaman ini belum dibudidayakan secara sungguhsungguh sementara potensi tanaman ini dalam menghasilkan gula merah dan minuman tradisional Tuak cukup besar dan kemungkinan untuk dikembangkan sebagai penghasil Alkohol untu bahan bakar sangat memungkinkan.

Tanaman aren ini adalah tanaman multi manfaat, karena hampir seluruh bagian dari tanaman ini dapat dimanfaatkan, seperti nira (bahan utama gula aren, minuman, cuka dan alkohol), sumber enargi bioethanol, sumber karbohidrat (tepung), bahan campuran minuman 
(kolang-kaling) dan sebagai tanaman konservasi untuk lahan-lahan kritis.

Pratiwi dan Alrasjid, (1989) secara ekologis tanaman aren dapat berfungsisebagai pendukung habitat dari fauna tertentu dan dapat mendukung program konservasi tanah dan air .

Selain itu tipe morfologi tanaman aren yang dapat tumbuh liar pada ketinggian $0-1.500 \mathrm{~m}$ dpl pada tanah rakyat yang ada di Kabupaten Tapanuli Selatan, juga mempunyai karakter yang berbeda, sehingga kemungkinan sifat morfologi dari tanaman itu juga membedakan produksi dari tanaman aren itu sendiri.

$\begin{array}{rrrr} & \text { Tanaman } & \text { aren } & \text { adalah } \\ \text { tanaman } & \text { yang } & \text { tidak } & \text { terlalu }\end{array}$ memerlukan kondisi iklim dan tanah yang spesipik untuk mendukung pertumbuhannya. Dinas Kehutanan Jawa Tengah (2011), mangatakan bahwa aren bisa tumbuh subur di tengah pepohonan lain dan semaksemak, di dataran, lereng bukit, lembah, dan gunung hingga ketinggian 1.400 mdpl. Akar tanaman yang bisa mencapai kedalaman 6-8 meter ini dapat menahan erosi, serta sangat efektif menarik dan menahan air.

Berdasarkan permasalahan di atas perlu kajian tentang tanaman Aren ini sehubungan dengan sifat morfologi tanaman berdasarkan skuen ketinggian tempat di Kabupaten Tapanuli Selatan yang mungkin dapat menjadi pintu masuk untuk mulai membudidayakan tanaman ini.

Penelitian ini bertujuan Untuk mengetahui hubungan sifat morfologi tanaman terhadap produksinya berdasarkan skuen ketinggian tempat di Kabupaten Tapanuli Selatan.

\section{BAHAN DAN METODE}

Lokasi yang menjadi kajian penelitian ini yaitu Desa Situmba dan Desa PanabariKecamatan Tano Tombangan Angkola dengan ketinggian 0 - $400 \mathrm{~m}$ dpl, Desa Pasar Sempurna, Desa Gunungtua, Desa Aek Nabara Kecamatan Marancar dengan ketinggian $400-800 \mathrm{~m}$ dpldan Desa Sialaman Julu, Desa Sialaman Jae Kecamatan Sipirok dengan ketinggian $>800 \mathrm{~m}$ dpl dan dimasing-masing ketinggian diambil 10 pohon sampel.

Pengambilan sampel nira diambil dari masing-masing tanaman yang dijadikan tanaman sampel untuk dianalisa kadar niranya. Untuk setiap jenis ketinggian tempat diambil sebanyak 10 sampel tanah dan sampel Nira. Untuk penghitungan rata-rata produksi nira maka dilakukan perhitungan terhadap hasil nira yang dihasilkan/pohon selama 1 (satu) minggu. Sedangkan nira diambil dari masing-masing tanaman yang dijadikan sampel untuk dianalisa kadar gulanya.

Data diolah dengan menggunakan analisis regresi linier Berganda dengan model linier sebagai berikut :

$\mathrm{Y}=\mathrm{a}+\mathrm{b} 1 \mathrm{X}_{1}+\mathrm{b} 2 \mathrm{X}_{2}+\ldots+\mathrm{B}_{6} \mathrm{X}_{6}$

Parameter Morfologi tanaman terdiri dari Tinggi Tanaman, Umur Tanamam, Diameter Batang, Umur Sadapan, Tingkatan Malai, dan Jumlah Klorofil a dan b.

Proses pengolahan nira menjadi gula aren dilakukan dengan cara memasak nira tersebut dengan menggunakan kuali. Bahan bakar yang digunakan untuk memasak 
tersebut adalah kayu bakar. Nira aren sebanyak 3 liter dipanaskan selama 1,5 jam dimana nira akan menjadi kental dan berwarna merah kecoklatcoklatan yang kemudian nira yang sudah kental tersebut dimasukkan kedalam cetakan yang sudah dipersiapkan. Setelah gula aren tersebut kering dan dingin maka dilakukan penimbangan terhadap gula aren tersebut.

\section{HASIL DAN PEMBAHASAN}

Hasil penelitian membahas tentang kajian produktifitas tanaman aren berdasarkan sifat morpologi tanaman (umur tanaman, tinggi tanaman, diameter batang, umur sadapan tingkatan malai, klorofil a, b dan klorofil total). Data dari pada produksi nira dan produksi gula akibat dari pengaruh peubah sifat morpologi tanaman aren pada masing-masing ketinggian tempat dapat diketahui bahwa produksi nira tertinggi dijumpai pada tanaman sampel 4 di daerah Desa Marancar dengan produksi nira sebanyak 25,8 ltr/pohon/hari pada ketinggian tempat $600 \mathrm{~m} \mathrm{dpl}$, sedangkan yang terendah dijumpai pada tanaman sampel 6 di daerah Desa Tano Tombangan dengan produksi 3,93 ltr/pohon/hari pada ketinggian 290 $\mathrm{m} \mathrm{dpl} \mathrm{.}$

Kadar gula tertinggi dijumpai pada tanaman sampel 4 di Desa Tano Tombangan dengan kadar gula sebesar 17,33 \% dan yang terendah dijumpai pada tanaman sampel ke 1di Desa Sialaman dengan kadar gula $10 \%$. Sedangkan produksi gula tertinggi dijumpai pada tanaman sampel 4 di daerah Desa Marancar dengan produksi gula 3,53 $\mathrm{kg} /$ pohon/hari, dan yang terendah pada tanaman sampel 3 di Desa Tano Tombangan dengan produksi gula sebanyak $0,59 \mathrm{~kg} /$ pohon/hari.

\section{Analisa Pertumbuhan}

Hasil penelitian terhadap analisa pertumbuhan tinggi tanaman yang dijumpai pada semua lokasi penelitian menunjukkan bahwa tinggi tanaman pada kisaran antara 7 - 21,63 meter.

Tabel 1. Hubungan Antara Tinggi Tanaman Dengan Produksi Nira Dan Jumlah Gula

\begin{tabular}{|c|c|c|c|c|}
\hline $\begin{array}{l}\text { Tinggi Tan } \\
\text { (TT) }\end{array}$ & Persamaan Regresi & $\mathrm{R}$ & $\mathrm{R}^{2}$ & Ket \\
\hline \multicolumn{5}{|l|}{ Produksi Nira } \\
\hline $\mathrm{T} 1$ & $\mathrm{Y}=1,897+0,500 \mathrm{TT}$ & 0,411 & 0,169 & $*$ \\
\hline $\mathrm{T} 2$ & $\mathrm{Y}=10,369+0,291 \mathrm{TT}$ & 0,154 & 0,024 & tn \\
\hline $\mathrm{T} 3$ & $\mathrm{Y}=8,780-0,018 \mathrm{TT}$ & 0,024 & 0,0006 & tn \\
\hline \multicolumn{5}{|l|}{ Jumlah Gula } \\
\hline $\mathrm{T} 1$ & $\mathrm{Y}=0,229+0,075 \mathrm{TT}$ & 0,513 & 0,280 & $*$ \\
\hline $\mathrm{T} 2$ & $\mathrm{Y}=1,174+0,057 \mathrm{TT}$ & 0,206 & 0,042 & $*$ \\
\hline $\mathrm{T} 3$ & $0,880+0,015 \mathrm{TT}$ & 0,111 & 0,012 & $\operatorname{tn}$ \\
\hline
\end{tabular}

Hubungan keeratan antara tingi tanaman dengan produksi nira serta jumlah gula yang dihasilkan dapat dilihat pada Tabel 1, dimana secara umum memiliki hubungan yang positif yang artinya semakin tinggi tanaman maka produksi nira 
dan jumlah gula yang dihasilkan akan meningkat.

Sebagaimana diketahui bahwa tanaman aren adalah tanaman yang tumbuh liar di hutan, dimana hutan tersebut ditanami berbagai jenis tanaman sehingga terjadi persaingan diantara sesama tanaman untuk memperoleh cahaya matahari yang dianggap sebagai sumber energi di dalam proses fotosintesa. Hal ini sesuai dengan pendapat Hay dan Fitter (1991) menyatakan bahwa pengaruh utama dari perubahan dalam kerapatan pengaliran terjadoi pada proses yang menggunakan cahaya sebagai suatu sumber energi pada proses fotosintesa.

\section{Tumbuh-tumbuhan}

memakan zaty-zat anorganik yang diambilnya dari atmosfer dan dari dalam bumi, dijadikan zat-zat organik dengan bantuan sinar matahari dalam proses fotosintesis (Irwan, 2010).

Demikian juga halnya dengan diameter batang yang pada penelitian ini dijelaskan bahwa pengaruh diameter batang secara umum tidak berbeda nyata. Hubungan keeratan antara diameter batang dengan produksi nira dan jumlah gula yang dihasilkan dapat dilihat pada Tabel 2, dimana secara keseluruhan mmemiliki hubungan yang negatif yang artinya setiap kenaikan diameter batang tidak akan meningkatkan produksi nira maupun jumlah gula yang dihasilkan.

Hal ini disebabkan karena tanaman aren di dalam mempergunakan hasil asimilatnya lebih banyak digunakan untuk perkembangan vegetatif tanaman yang dalam hal ini adalah perkembangan diameter batang, sehingga perkembangan generatifnya yaitu pembentukan bunga yang kemudian menjadi buah dan biji akan terhambat. Sebagaimana diketahui bahwa hasil utama dari pada tanaman aren adalah produksi nira yang diperoleh dari hasil sadapan bunga jantan

Tabel 2. Hubungan Antara Diameter Batang Dengan Produksi Nira Dan Jumlah Gula

\begin{tabular}{crccc}
\hline Diameter Btg & Persamaan Regresi & $\mathrm{R}$ & $\mathrm{R}^{2}$ & Ket \\
\hline $\begin{array}{c}\text { Produksi Nira } \\
\text { T1 }\end{array}$ & $\mathrm{Y}=12,598-0,198 \mathrm{DB}$ & 0,419 & 0,176 & tn \\
T2 & $\mathrm{Y}=28,348-0,552 \mathrm{DB}$ & 0,392 & 0,154 & $*$ \\
T3 & $\mathrm{Y}=11,952-0,137 \mathrm{DB}$ & 0,461 & 0,173 & tn \\
Jumlah Gula & & & & \\
T1 & $\mathrm{Y}=1,598-0,020 \mathrm{DB}$ & 0,355 & 0,126 & th \\
T2 & $\mathrm{Y}=4,271-0,090 \mathrm{DB}$ & 0,435 & 0,189 & tn \\
T3 & $\mathrm{Y}=1,308-0,010 \mathrm{DB}$ & 0,188 & 0,035 & tn \\
& & & & \\
\hline
\end{tabular}

Seiring dengan perkembangan tinggi tanaman dan diameter batang yang dibarengi dengan bertambahnya umur tanaman, dimana hasil penelitian yang dijumpai pada lokasi penelitian ternyata umur tanaman berada pada kisaran $9-12,5$ tahun.

Hasil penelitian menunjukkan umur tanaman tidak berbeda nyata terhadap produksi nira dan jumlah gula yang dihasilkan, 
sedangkan hubungan keeratannya memiliki hubungan yang negatif dimana setiap pertambahan umur tanaman maka produksi nira dan jumlah gula yang dihasilkan akan mengalami penurunan.

Tabel 3. Hubungan Antara Umur Tanaman Dengan Produksi Nira Dan Jumlah Gula.

\begin{tabular}{ccccc}
\hline $\begin{array}{c}\text { Umur Tan. } \\
\text { (UT) }\end{array}$ & Persamaan Regresi & $\mathrm{R}$ & $\mathrm{R}^{2}$ & Ket \\
\hline $\begin{array}{c}\text { Produksi Nira } \\
\text { T1 }\end{array}$ & $\mathrm{Y}=17,097-0,881 \mathrm{UT}$ & 0,259 & 0,067 & tn \\
T2 & $\mathrm{Y}=38,737-2,358 \mathrm{UT}$ & 0,418 & 0,175 & tn \\
T3 & $\mathrm{Y}=2,914-0,428 \mathrm{UT}$ & 0,275 & 0,076 & tn \\
Jumlah Gula & & & & \\
T1 & $\mathrm{Y}=1,772-0,063 \mathrm{UT}$ & 0,155 & 0,024 & tn \\
T2 & $\mathrm{Y}=5,052-0,294 \mathrm{UT}$ & 0,534 & 0,285 & tn \\
T3 & $\mathrm{Y}=1,078-0,001 \mathrm{UT}$ & 0,003 & 0,000009 & tn \\
& & & & \\
\hline
\end{tabular}

Sebagaimana diketahui menurut PT.BUMN Hijau Lestari 1 (2011) bahwa tanaman aren dapat dipanen pertama pada usia $8-20$ tahun tergantung pada jenis aren yang ditanam. Ciri tanaman yang sudah siap di panen biasanya ditandai dengan keluarnya bunga jantan (langgari).

Pendapat ini diperkuat oleh Soeseno (1991) mengatakan bahwa bunga-bunga itu muncul di ketiak daun di bawah tempat munculnya beluluk, kira-kira pada umur $8-10$ tahun.

Di dalam penelitian ini karena tanaman aren yang dijadikan sebagai sampel adalah tanaman aren yang tumbuh liar di hutan Kabupaten Tapanuli Selatan, dimana jenis aren yang ditanam tidak jelas diketahui karena aren yang tumbuh adalah aren yang dikecambahkan dari muntahan musang. Oleh karenanya penulis mengambil kesimpulan bahwa panen pertama pada malai tingkatan 1 dimulai pada umur 9 tahun.

Menurunnya produksi nira seiring dengan bertambahnya umur tanaman adalah disebabkan oleh tingkatan malai yang disadap juga menurun mulai dari tingkatan malai 1 sampai dengan seterusnya sampai tanaman tidak menghasilkan.

Dalam penelitian ini tingkatan malai yang ditemukan dilapangan berada pada kisaran antara $1-7$. Hubungan antara tingkatan malai dengan produksi nira dan jumlah gula yang dihasilkan sebagaima dilihat pada Tabel 4, menunjukkan tidak berbeda nyata dan terdapat hubungan yang negatif dimana setiap peningkatan malai maka produksi nira dan jumlah gula yang dihasilkan akan menurun.

Penurunan produksi nira ini disebabkan oleh semakin tuanya tanaman aren yang menungkinkan tanaman semakin tidak produktif untuk mengasilkan bahan makanan. Soeseno (1991) mengatakan bahwa pohon aren bisa disadap niranya selama $3-4$ tahun, sebelum persediaan bahan makanan dalam teras batang yang membentuk nira itu habis. Pendapat ini didukung oleh Mahmud et al (1991), yang menyatakan bahwa aren dapa disadap niranya dari tandan bunga 
jantan selama 3 - 5 tahun. Sesudah itu pohon tidak produktif lagi dan lama kelamaan mati.

Faktor lain yang mempengaruhi produksi nira adalah

Tabel 4. Hubungan Antara Tingkatan Malai Dengan Produksi Nira Dan Jumlah Gula

\begin{tabular}{ccccc}
\hline $\begin{array}{c}\text { Tingkatan } \\
\text { Malai }\end{array}$ & Persamaan Regresi & $\mathrm{R}$ & $\mathrm{R}^{2}$ & $\mathrm{Ket}$ \\
\hline $\begin{array}{c}\text { Produksi Nira } \\
\text { T1 }\end{array}$ & $\mathrm{Y}=9,167-0,441 \mathrm{TM}$ & 0,259 & 0,067 & $\mathrm{tn}$ \\
T2 & $\mathrm{Y}=18,505-1,388 \mathrm{TM}$ & 0,377 & 0,142 & $\mathrm{tn}$ \\
T3 & $\mathrm{Y}=9,203-0,287 \mathrm{TM}$ & 0,223 & 0,049 & $\mathrm{tn}$ \\
Jumlah Gula & & & & \\
T1 & $\mathrm{Y}=1,201-0,032 \mathrm{TM}$ & 0,155 & 0,024 & tn \\
T2 & $\mathrm{Y}=2,526-0,172 \mathrm{TM}$ & 0,318 & 0,101 & tn \\
T3 & $\mathrm{Y}=1,161-0,040 \mathrm{TM}$ & 0,182 & 0,033 & tn
\end{tabular}

umur sadapan yang dilakukan pada tingkatan malai. Data yang diperoleh dalam penelitian ini menyangkut umur sadapan berada pada kisaran 7 - 105 hari.

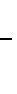


lambat yang mengakibatkan produksinya menurun. Lama kelamaan walaupun potensi tanaman sudah mulai berkurang untuk menghasilkan nira tetapi posisi tangkai malai sudah mulai lurus akibat terus menerus disadap, sehingga tekanan air dari pada malainya akan saemakin meningkat (Tidak dihalangi oleh malai yang bengkok) yang menyebabkan produksi nira akan meningkat kembali. Tapi kondisi ini tidak bisa bertahan lama dikarenakan tanaman juga semakin lama produksinya juga akan semakin menurun.

Tabel 6. Hubungan Antara Khloropyl a Dengan Produksi Nira Dan Jumlah Gula

\begin{tabular}{clrrr}
\hline Klorofil a & Persamaan Regresi & $\mathrm{R}$ & $\mathrm{R}^{2}$ & Ket \\
\hline Produksi Nira & & & & \\
T1 & $\mathrm{Y}=6,875+0,029 \mathrm{a}$ & 0,039 & 0,002 & tn \\
T2 & $\mathrm{Y}=8,056+0,298 \mathrm{a}$ & 0,375 & 0,141 & $*$ \\
T3 & $\mathrm{Y}=9,297-0,035 \mathrm{a}$ & 0,118 & 0,014 & th \\
Jumlah Gula & & & & \\
T1 & $\mathrm{Y}=1,390-0,011 \mathrm{a}$ & 0,131 & 0,017 & tn \\
T2 & $\mathrm{Y}=0,838+0,054 \mathrm{a}$ & 0,459 & 0,211 & $*$ \\
T3 & $\mathrm{Y}=1,346-0,013 \mathrm{a}$ & 0,253 & 0,064 & tn
\end{tabular}

Klorofil adalah pigmen utama di dalam tanaman yang berperan dalam proses fotosintesa, dimana dalam penelitian ini kisaran klrofil, baik klorofil a,b dan total yang ditemukan di lapangan adalah $7,81-31,79 \mathrm{mg} / \mathrm{g}$. Hubungan keeratan antara klorofil dengan produksi nira dan jumlah gula yang dihasilkan dapat dilihat masingmasing pada Tabel 13, 14 dan 15 dimana dapat kita lihat bahwa pada daerah T1 dan T3 klorofil tidak berbeda nyata dimana terdapat hubungan negatif yang artinya dengan peningkatan klorofil maka produksinya akan semakin menurun. Sedangkan pada daerah T2 berbeda nyata dan terdapat hubungan yang positif diamana dengan peningkatan klorofil dibarengi dengan peningkatan produksi nira dan jumlah gula yang dihasilkan.
Kondisi ini mungkin terjadi karena $\mathrm{pH}$ tanah yang dijumpai di lokasi penelitian tergolong masam sehingga kandungan Magnesium $(\mathrm{Mg})$ sebagai salah satu unsur penyusun klorofil tidak dapat diserap oleh tanaman secara maksimal.

\section{Ketinggian Tempat}

Ketinggian tempat adalah merupakan faktor penentu dimana suatu tanaman dapat tumbuh dengan baik sesuai dengan karakter dari pada tanaman itu sendiri. Dalam penelitian ini kisaran ketinggian tempat yang ditemukan berada pada kisaran 260 $1075 \mathrm{~m}$ dpl, dimana hubungan keeratan antara ketinggian tempat dengan produksi nira dan jumlah gula yang dihasilkan dapat dilihat pada Gambar 1, secara statistik menyatakan tidak berbada nyata dan terdapat hubungan yang positif terhadap produksi nira yang artinya setiap kenaikan ketinggian tempat. 
Sedangkan untuk jumlah gula yang dihasilkan dinyatakan tidak berbeda nyata dan terdapat hubungan yang negatif dimana setiap peningkatan ketinggiuan tempat maka jumlah gula yang dihasilkan akan semakin menurun.

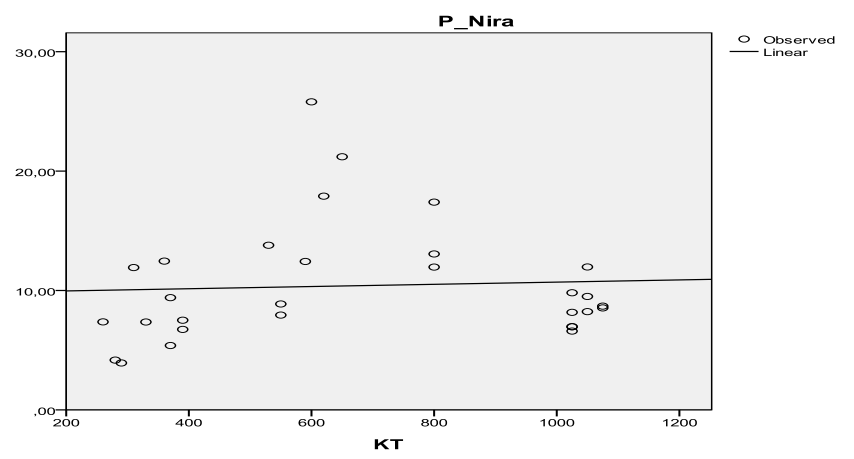

Gambar 1 : Hubungan Antara Produksi Nira dengan Ketinggian Tempat

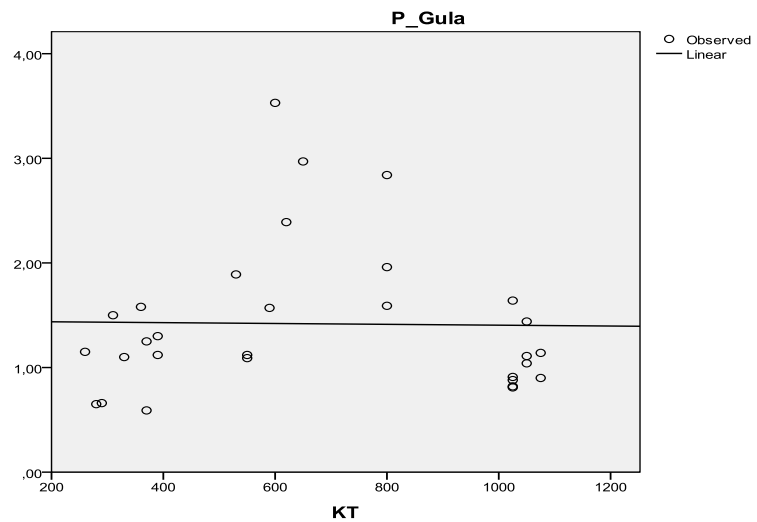

Gambar 2 : Hubungan antara Jumlah Gula Yang Dihasilkan Dengan Ketinggian Tempat

Kalau kita perhatikan sebaran produksi nira akibat ketinggian tempat sebagaimana terlihat pada gambar ..... dapat dinyatakan bahwa semakin tinggi ketinggian tempat maka produksi nira akan semakin menurun. Dan ternyata produksi nira yang tertinggi kita jumpai pada kisaran $500-800$ m dpl.

Hal ini terjadi karena memang faktor lingkungan sangat mempengaruhi proses-proses fisiologi di dalam tanaman. Sebagaimana disampaikan oleh Verne, (2010) yang mengatakan bahwa emua proses fisiologi akan dipengaruhi oleh suhu dan beberapa proses akan tergantung kepada cahaya. Suhu optimum sangat diperlukan oleh tanaman agar dapat dimamfaatkan sebaik-baiknya oleh tanaman. Suhu yang terlalu tinggi akan menghambat pertumbuhan tanaman bahkan akan mengakibatkan kematian bagi tanaman, demikian pula sebaiknya suhu yang terlalu rendah. Suhu berpengaruh terhadap pertumbuhan vegetatif, induksi bunga, pertumbuhan dan differensiasi pembungaan, mekar bunga, munculnya serbuk sari, 
pembentukan benih dan pemasakan benih.

Dari hasil penelitian mengatakan bahwa perbedaan suhu pada titik pengamatan ditiap satuan lahan merupakan pengaruh perbedaan ketinggian tempat, karena setiap kenaikan $100 \mathrm{~m}$ pada tofografi, suhunya meningkat pula sebesar $1^{0} \mathrm{C}$ (Puturuhu, 2011).

Sedangkan penurunan Jumlah gula yang dihasilkan, ini berhubungan dengan produksi nira dimana semakin tinggi produksi niranya maka kadar gula yang terkandung di dalamnya akan mengalami penurunan yang artinya kadar airnya lebih tinggi dari pada kadar gulanya sehingga akan kita jumpai produksi gula yang tinggi adalah pada produksi nira yang lebih rendah.

\section{SIMPULAN}

Hubungan tinggi tanaman, diameter batang, jumlah malai,klorofil dan ketingian tempat,memiliki korelasi positif dengan jumlah gula aren, walaupun secara statistic tidak nyata, karena banyak fakrot yang mempengaruhi jumlah gula (produksi aren).

\section{DAFTAR PUSTAKA}

Aenur, R. Dan Endang, M. 2008.

Pengaruh Perlakuan

Deoperkulasi dan Media

Perkecambahan Untuk

Meningkatkan Viabilitas

Benih Aren (Arenga pinnata

Merr.). Bul. Agron. (36) (1).

Mukhlis, 2007. Analisa Tanaman.

USU press.

Badan Pusat Statistik Kabupaten

Tapanuli Selatan, 2010.
Tapanuli Selatan Dalam

Angka 2010.

Balitka. 1992. Prospek Tanaman

Kelapa, Aren, Lontar Dan

Gewang Untuk

Menghasilkan Gula. Media

Komunikasi Penelitian Dan

Pengembangan Tanaman

Industri.

Bayong, T.H.K. 2004. Klimatologi.

ITB Bandung.

Dinas Kehutanan Jawa Tengah, 2011. Budidaya Dan Potensi Pengembangan Tanaman

Aren.

Dinas Perkebunan Propinsi Sumatera Utara, 2011. Pengembangan

Komoditi Aren. UPTD

Wilayah

Padangsidimpuan.

Efendi ,D.S., 2010. Prospek Pengembangan Tanaman Aren (Arenga pinnata Merr)

Mendukung Kebutuhan

Bioetanol Indonesia. Pusat Penelitian Dan

Pengembangan Perkebunan. Jurnal Perspektif Vol. 9 No. 1 .

Fahmi, Z.I., 2011. Studi Tehnik Pematahan Dormansi Dan Media Perkecambahan Terhadap Viabilitas Benih Aren (Arenga pinnata (Wurmb.). Balai Besar Perbenihan Dan Proteksi Tanaman Perkebunan Surabaya.

Fitter, A.H. dan Hay, R.K.M. 1991.

Fisiologi Lingkungan

Tanaman. Gajah Mada

University Press.

Gomez and Gomez, 2007. Prosedur

Statistik Untuk Penelitian

Pertanian. Edisi Kedua.

Penerbit Universitas Indonesia. 
Hanafiah, K.A. 2010. Dasar-Dasar Ilmu Tanah. PT. Raja Grafindo Persada. Jakarta.

Hidayati, N., 2009. Mamfaat Pohon Aren.

http://niahidayati.net/manfa at-pohon-aren.htm.

Mailangkay R.B. 2007. Teknik Budidaya Dan Rehabilitasi Tanaman Aren . Bulletin Palma No. 33.

Maliangkai R.B. 2008. Sumber Benih Dan Persemaian Aren. Wrta Penelitian Dan Pengembangan Tanaman Industri.

Munawar, A. 2011. Kesuburan Tanah Dan Nutrisi Tanaman. IPB Press.

Muhammad, S.S. 2004. Pematahan Dormansi Benih Aren Secara Fisik Pada Berbagai Lama Ekstraksi Buah. Agrosains 6(2).

Mukhlis, 2007. Analisis Tanah Tanaman. USU press. Puturuhu, F., Johan, R., dan Albert J.N. 2011. Kondisi Fisik Lahan Tanaman Aren (Arenga pinnata L.) Di Desa Tuhaha Kecamatan Saparua Kabupaten Maluku Tengah. Jurnal Budidaya Pertanian, Vol. 7 No. 2.

Rindengan, B dan E. Manaroinsong, 2009. Aren. Tanaman Perkebunan Penghasil Bahan Bakar Nabati (BBM). Pusat Penelitian Dan Pengembangan Perkebunan.

Silahooy, ch. 2008. Efek Pupuk KCl dan SP-36 Terhadap Kalium Tersedia, Serapan Kalium dan Hasil Kacang Tanah(Arachis hypogaea L.) pada Tanah Brunizem. Bul. Agron. (36) (2).
Simanungkalit R.D.M., Didi A.S.,, Rasti S., Diah S., dan Wiwik H. 2006. Pupuyk organik Dan Pupuk Hayati. Balai Besar LitbangSumberdaya Laha PertanianBadan Penelitian dan Pengembangan Pertanian.

Soeseno, S., 1991. Bertanam Aren. Penebar Swadaya. Anggota IKAPI. Jakarta.

Suharno, Mawardi, I., Setiabudi, Lunga, N., dan Tjitrosemito, S. 2007. Efisiensi Penggunaan Nitrogen pada Tipe Vegetasi yangBerbeda di Stasiun Penelitian Cikaniki, Taman Nasional GunungHalimun Salak, Jawa Barat. Biodiversitas, Volume 8 Nomor 4.

Warta Penelitian Dan Pengembangan Pertanian, 2009. Aren, Sumber Energi Alternatif. Vol. 31 No. 2. 